\title{
A Study on Cross-cultural Teaching of Higher Vocational English Teaching
}

\author{
Ruoheng Zhao ${ }^{1, \text { a }}$ \\ ${ }^{1}$ XinJiang Agricultural Vocational Technical College, Changji 831100, China \\ a1469314226@qq.com
}

Keywords: Higher vocational English teaching;Cross-cultural; Method

Abstract. This paper gives a brief introduction of cross-cultural teaching and an analysis of the problems existing in cross-cultural teaching with the example of higher vocational English teaching, and presents corresponding solutions. Finally, this paper fully elaborates methods in higher vocational English teaching for the purpose of certain reference.

\section{Introduction}

Due to the influence many factors, such as history and region, there is great difference in Chinese and western culture. In English teaching, some articles are of profound western culture and it is difficult to comprehend those articles on the basis of Chinese culture, therefore, it is necessary to strengthen cross-cultural teaching and carry out studies on corresponding teaching methods for it is the key point in improving efficiency and quality of higher vocational English teaching and the basis for increasing students' interests in learning English and proficiency.

\section{Cross-cultural Teaching}

From the perspective of English teaching in China, cross-cultural teaching is a teaching method to improve students' ability to adapt and comprehend English through understanding of English culture so as to help them determine and think about questions from a viewpoint of western culture, and a main approach to cultivate students' interests in learning English and improve students' oral English. This method has been received high attention from from the education sector[1].

In English teaching, contents involved in cross-cultural teaching mainly include use of vocabulary and social customs etc.[2]: (1) take the word individualism for example, it means “个人主义” or “逞 强” in Chinese, and is of derogatory sense in China where collectivism is emphasized, however, in the western world, where individual consciousness is emphasized, it is used as a commendatory word. (2) Social customs: Christmas is the traditional festival in western countries with the customs of decorating Christmas trees and Christmas parade; whereas Spring Festival is the traditional festival in China with the customs of pasting Spring Festival couplets and having New Year's Eve dinner and so on. In a word, there are great differences in the customs.

Tab. 1 Differences in Chinese and Western Vocabulary

\begin{tabular}{|c|c|c|c|}
\hline Vocabulary & Connotation & Chinese Culture & Western Culture \\
\hline \multirow[t]{3}{*}{ individualism } & “个人主 & Emphasizing & Emphasizing \\
\hline & 义”、“逞强” & collectivism & $\begin{array}{l}\text { individual } \\
\text { consciousness }\end{array}$ \\
\hline & & Derogatory term & $\begin{array}{l}\text { Commendatory } \\
\text { term }\end{array}$ \\
\hline \multicolumn{4}{|c|}{ Tab. 2 Differences in Chinese and Western Social Customs } \\
\hline Festival & Decoration & $\begin{array}{l}\text { Relationship among } \\
\text { People }\end{array}$ & Food \\
\hline Christmas & Christmas tree & Exchanging Gifts & Turkey \\
\hline $\begin{array}{l}\text { Spring } \\
\text { Festival }\end{array}$ & $\begin{array}{l}\text { Spring festival } \\
\text { couplets }\end{array}$ & $\begin{array}{l}\text { Paying New Year calls to } \\
\text { each other }\end{array}$ & Dumplings \\
\hline
\end{tabular}


In consideration of the above mentioned differences, it is necessary to strengthen cultivation of students' cross-culture awareness in higher vocational English teaching so as to lay a solid foundation for improvement of their learning efficiency and quality.

\section{Existing Problems and Corresponding Solutions in Cross-cultural teaching of Higher Vocational English Teaching}

(I)Existing problems in cross-cultural teaching of higher vocation English teaching

As far as the present situation is concerned, problems in cross-cultural teaching such as weak awareness and low level of cross-cultural teaching of higher vocation English teaching are quite obvious and are mainly reflected in the following aspects (Tab. 3) [3]: teachers' accomplishments to be enhanced: English teachers lack understanding of western culture, which would fundamentally pull down the quality of cross-cultural teaching ;2) teaching programs to be improved: currently, higher vocation English teaching primarily covers "listening”, "speaking”, "reading” and "writing” and involves little Chinese and western culture; (3) teaching methods to be reformed: at the present, the traditional cramming method is still applied in higher vocation English teaching, through which, students can only accept knowledge passively and the teaching content is textbook-oriented with poor extending, thus, the cross-cultural teaching is under low teaching level.

Tab. 3 Existing Problems in Cross-cultural Teaching of Higher Vocational English Teaching

\begin{tabular}{cccc}
\hline Problems & Problem 1 & Problem 2 & Problem 3 \\
\hline Content & $\begin{array}{c}\text { Teachers' low } \\
\text { accomplishments }\end{array}$ & $\begin{array}{c}\text { Defective } \\
\text { teaching programs }\end{array}$ & $\begin{array}{c}\text { Teaching methods to be } \\
\text { reformed }\end{array}$ \\
\hline
\end{tabular}

(II) Solutions to the problems in cross-cultural teaching of higher vocation English teaching

The following methods can be adopted for improving the level of cross-cultural teaching of higher vocational English teaching (Tab. 4) [4]: (1) to improve teachers' accomplishments: teachers take part in training to enhance understanding of western culture and seek more chances to communicate with foreign teachers to deepen understanding of western culture; (2) to perfect teaching programs: cultural teaching shall be included in teaching programs and a culture block shall be set in each chapter; (3): to reform teaching methods before the class, teachers shall analyze the Chinese and western culture involved in this section and show such content to student in class. Meanwhile, teachers shall apply multimedia in teaching so as to strengthen intuitive of cross-cultural teaching by presenting pictures and videos. In addition, teachers can set a second classroom, for example, English corner, to encourage students to communicate with foreign students and organize students to carry out role play activities to understand the differences in Chinese and western culture.

Tab. 4 Solutions to Problems in Cross-cultural Teaching of Higher Vocation English Teaching

\begin{tabular}{cccc}
\hline Methods & Method 1 & Method 2 & Method 3 \\
\hline Content & $\begin{array}{c}\text { To enhance } \\
\text { teachers } \\
\text { accomplishments }\end{array}$ & $\begin{array}{c}\text { To improve } \\
\text { teaching programs }\end{array}$ & $\begin{array}{c}\text { To reform } \\
\text { teaching methods }\end{array}$ \\
\hline
\end{tabular}

\section{Case Analysis of Methods Applied in Cross-cultural Teaching of Higher Vocational English Teaching}

In higher vocational English teaching, an analysis of methods applied in cross-cultural teaching with the example of teaching of articles related to Christmas.

(I) Teaching objectives

(1)To master spelling, reading and ways to use the latest vocabulary; (2) To know Christmas customs in the western world; (3) To know the differences in customs of traditional festivals and strengthen cross-cultural awareness.

(II) Cross-cultural teaching methods

1. Preparation before class 
Before the class, the teacher shall tell students to gather in advance knowledge about Christmas by watching Christmas videos or looking up to relevant documents. The teacher shall also actively collect corresponding content and compare the differences in traditional Chinese and western festivals.

2. Classroom teaching

(1) Introduction: multimedia is used to play jingle belles for the students to introduce the subject of this lesson -- Christmas; (2) text reading and extraction of cross-cultural knowledge: the students are divided into several groups, each of which reads different paragraphs of the text. And after reading, the content concerning cross-culture shall be found to train students' ability to recognize cross-cultural knowledge; (3) Interpretation of Cross-cultural knowledge: explanation of vocabulary: the teacher explains names of the characters: for Chinese names, the family name is before the given name to stress lineage relation and collectivism; however, for English names, the given name is before the family name to stress individualism and independent awareness. Interpretation of customs: on Christmas in the western world, people exchange gifts with each other; on Spring Festival in China, people pay a New Year's Visit to each other. Besides, on Christmas in the western world, decoration is mainly made on the Christmas tree and on Spring Festival in China, decoration is reflected by the couplets. The interpretation proceeds along with picture presentation via multimedia; (4) cultural communication: students in the same groups play as Chinese and British respectively and communicate with each other on Christmas and Spring Festival. Students are told to make dialogues by themselves and act out the dialogues so that they can deepen understanding of cross-cultural knowledge.

(III) After-class practice

The teacher organizes get-together for Chinese and foreign students to help them build a friendly relationship and through the communication in English, students can be in close contact with western culture, know values and behavior modes of the westerners so as to enhance cross-cultural teaching level.

\section{Conclusion}

To sum up, in higher vocation English teaching, we shall attach high importance to cross-cultural teaching, optimize classroom teaching methods, improve students' understanding of cross-cultural knowledge and improve efficiency of English teaching.

\section{References}

[1]Li P. An Inquiry into the Application of the Theory of Multiple Intelligences to Higher Vocational English Teaching[J]. Biomacromolecules, 2009, 10(11):2961-7.

[2]Xia K. Exploration on the scaffolding instruction mode in higher vocational oral English teaching guided by the constructivism theory[J]. Bioresource Technology, 2015, 191(1):146-156.

[3]Ani, Nur Yeti, Syahrial S, Mulyadi M. A STUDY OF ENGLISH TEACHERS ' CORRECTION IN SPEAKING ACTIVITIES AT GRADE XI IN A SELECTED VOCATIONAL SCHOOLKOTA BENGKULU 2012/2013 ACADEMIC YEAR[J]. Annals of Thoracic Surgery, 2013, 85(2):406-11.

[4]Rohn H, Tiemeyer E, Baedeker C, et al. Development of European competences for sustainability : vocational training in the sector of food and nutrition ; the project eukona - curricula and teaching/learning material for vocational education[J]. Acta Obstetricia Et Gynecologica Scandinavica, 2008, 85(11):1327 - 1330. 